\title{
MEMBACA KONSEP KASIH DALAM INJIL YOHANES MENGGUNAKAN LENSA HERMENUTIK MISIONAL
}

\author{
Matheus Mangentang, Tony Salurante \\ Sekolah Tinggi Teologi Injili Arastamar (SETIA) Jakarta \\ matheusmangentang@gmail.com, tony.salurante@sttsetia.ac.id
}

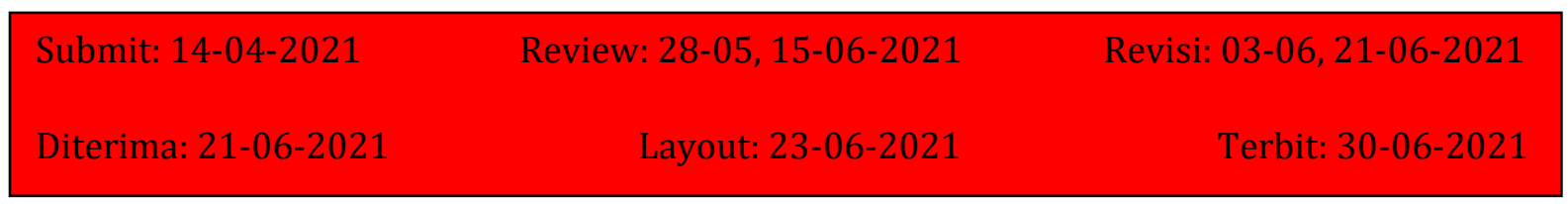

\begin{abstract}
This research attempt to show values from the concept of love in John's theology, especially in the Gospel, using a missional approach as a hermeneutic. This approach shows that the source of love is in the middle of the world because of God's mission to save humanity. Love is essential that unites the relationship between man and God. In addition, God can be known in the world because demonstrated by Christ in the cross. The church as a community of believers become a source of love because Her lives in the true love and fruitful. Love as one of the main teaching in the Gospel of John becomes a special theme in understanding God's mission from beginning to the end.
\end{abstract}

Keywords: Hermeneutics; God's Love; Missional hermeneutics; Missional church; Love; Johannine Theology; God Mission;

\begin{abstract}
Abstrak
Penelitian berusaha membukti nilai-nilai ajaran tentang kasih dalam teologi Yohanes khususnya dalam kitab Injil dengan menggunakan pendekatan misional sebagai sebuah hermenutik. Dengan pendekatan ini menunjukkan bahwa sumber kasih ada di tengah dunia karena misi Allah dalam menyelematkan manusia. Kasih menjadi esensi yang menyatukan hubungan manusia dan Allah. Selain itu Allah bisa dikenal di dunia karena kasih yang didemonstrasikan oleh Kristus. Gereja sebagai komunitas orang percaya merupakan sumber-sumber kasih sejati karena ia hidup didalam kasih sejati dan berbuah. Kasih sebagai salah satu pesan utama dalam Injil Yohanes menjadi sebuah tema yang spesial dalam memahami misi Allah dari awal sampai akhir.
\end{abstract}

Kata Kunci: Hermenutika; Kasih Allah; Hermenutika missional; Gereja misi; Kasih; Teologi Yohanes; misi Allah;

\section{PENDAHULUAN}

Kasih dalam kekristenan merupakan karakter Allah yang telah ada dalam kekekalan yang dinyatakan dalam banyak cara dalam sejarah. Karena Allah adalah kasih maka sumber kasih dalam setiap manusia hanya berasal dari Allah sejati dalam Alkitab. Namun demikian, banyak masalah yang bisa ditimbulkan karena kasih. Salah satunya adalah klaim dari berbagai ajaran yang mengatakan bahwa kasih bukanlah milik kekristenan yang unik. Sebaliknya, kasih dipraktikkan dan disebarkan oleh banyak 
gerakan religius dan humanis, baik kuno maupun modern. ${ }^{1}$ Beberapa pandangan dalam pikiran populer dan juga dalam ilmu sains menyatakan bagaimana manusia membutuhkan kasih untuk hidup. Hal ini merupakan kebutuhan dasar manusia manapun dan kapanpun. Meskipun ada konsesi yang tersebar luas mengenai asal mula kasih - apakah itu dari sebuah kuasa ilahi, manusia, pemikiran evolusioner, dari biologis, atau budaya manusia? Singkatnya, tidak ada yang mempertanyakan fakta bahwa setiap manusia di muka bumi ini membutuhkan kasih untuk mengembangkan kepribadian, dasar etika, dan pandangannya tentang kehidupan. Mendiskusikan tema kasih masih memiliki relevansi bagi umat manusia dan kekristenan secara khusus.

Dalam kekristenan seseorang yang mengalami cinta kasih tampaknya menciptakan dalam diri dorongan untuk saling mengasihi. Tetapi apakah proses seperti ini benar. Apakah nasihat untuk saling mengasihi hanya sekadar perintah ilahi yang berdampak eskatologis atau sementara saja. Penggunaan kata kasih dalam Alkitab tidak sebanyak kata Allah, namun kasih adalah salah satu gagasan penggerak dalam Alkitab, tidak tercermin dalam dari jumlah penggunaannya yang menonjol, tetapi topiknya lebih penting.

Pertanyaan yang muncul model mana yang dapat menguatkan studi eksegesis dalam memahami teks dari Alkitab. Apakah semua model bisa dipakai? Artikel singkat ini tidak bertujuan untuk memperdebatkan mana yang biblikal atau tidak. Tulisan ini hendak mengaplikasikan sebuah hermenutik misional sebagai metode yang biblikal untuk mengintepretasikan teks Alkitab. Alkitab adalah buku misional yang di dalamnya mencatat karya Misi Allah. Setiap bagiannya mengandung kerinduan Allah untuk membawa manusia sebagai ungkapan misional Allah. Seseorang akan selalu membaca ayat dalam Alkitab melalui lensa budaya, latar belakang teologis dan pengalaman pribadi, hal ini yang membentuk interpretasi seseorang. Pesan Injil dan budaya terikat erat satu sama lain sehingga masalah kontekstualisasi akan selalu muncul di setiap perubahan zaman. Dalam kekristenan sampai saat ini misi tetap hal utama meskipun terus mengalami perubahan zaman. Allah menciptakan gereja dan mengutusnya melintasi waktu, budaya, dan batas-batas yang lain. Dalam situasi yang cepat berubah dan situasi covid 19, gereja terus bertanya bagaimana tetap setia dalam melihat dan selalu terbuka untuk melakukan tugas mulia tersebut. Peran apa yang harus dimainkan gereja dalam mendorong atau membatasi ekspresi yang beragam dari iman Kristen? Orang percaya dan gereja yang mencintai misi namun tidak semua memahami bagaimana makna misi dalam teologi Yohanes jika dikaitkan dengan kasih.

Penelitian ini ingin menunjukkan bahwa beberapa model hermenutik sangat baik dan berguna bagi gereja di setiap konteks, namun apa yang ditawarkan Hermenutik Misional memberikan dimensi baru yang tepat bagi zaman ini. Membaca Alkitab dengan cara misional tidak menyebabkan seseorang harus selalu menemukan makna penginjilan di setiap ayat, bagi Wright bahwa sentral misional hermeneutis adalah karya Kristus yang dimaknai sebagai perbuatan misi Allah. ${ }^{2}$ Pandangan Wright ingin menunjukkan jika sifat misi adalah fondasi utama yang seharusnya ada di setiap hermenutik. Namun, selama ini gereja telah memisahkan misi dari semua bidang dalam dunia teologi dan eklesiologi. Bisa disimpulkan bahwa ini semua dampak dari penafsiran yang salah dan tidak kontekstual lagi. Menyadari bahwa pendekatan ini akan memberi banyak manfaat bagi gereja di Indonesia. Salah satu tulisan yang membahas ini dalam konteks Indonesia adalah Ailsa Baker dengan Judul artikelnya Teologi, Studi Biblikal dan Misi.

\footnotetext{
${ }^{1}$ Werner G. Jeanrond, $A$ Theology of Love (New York: T\&T Clark International, 2010), 26.

${ }^{2}$ Christopher J. H. Wright, "Mission as a Matrix for Hermeneutics and Biblical Theology," in Out of Egypt: Biblical Theology and Biblical Interpretation, ed. Craig Bartholomew et al. (Grand Rapids: Zondervan, 2004), 108.
} 
Artikel ini menegaskan bagaimana salah satu ajaran dalam Alkitab tentang kasih bukan saja memiliki makna luas bagi pembangunan doktrinal gereja namun juga misional yang penting dan perlu terus digali. Yesus berbicara tentang perintah kasih yang harus diteladani para murid-Nya. Ia berkata: "tinggallah di dalam kasih-Ku itu" (15:9) dan Yesus menyebutkan syaratnya dengan berkata: "Jikalau kamu menuruti perintah-Ku, kamu akan tinggal di dalam kasih-Ku." Namun di ayat 16 Yesus berkata: "bukan kamu yang memilih Aku tetapi Akulah yang memilih kamu." Banyak pandangan dari para sarjana Perjanjian Baru yang menyatakan bahwa perintah ini terbatas bagi para murid saja. ${ }^{3}$ Jika ini yang diterima maka kasih dalam Alkitab menjadi ajaran eksklusif yang sempit. Kegagalan dalam memahami dan menerapkan ajaran kasih tentu menjadi begitu signifikan, sebagaimana dilontarkan Carson, "Salah satu hasil paling berbahaya dari dampak versi kasih sentimental kontemporer pada Gereja adalah ketidakmampuan kita yang tersebar luas untuk memikirkan pertanyaan-pertanyaan mendasar yang memungkinkan kita untuk mempertahankan doktrin Allah dalam proporsi dan keseimbangan alkitabiah. Betapapun mulianya dan istimewa sebuah tugas yang mungkin, tidak ada yang mudah. Kita berurusan dengan Tuhan, dan reduksionisme yang konyol pasti menyimpang dan berbahaya."4 Carson menggambarkan situasi yang sering terjadi di banyak komunitas iman percaya yang gagal atau terlalu sempit memikirkan ajaran kasih.

\section{METODOLOGI PENELITIAN}

Metodologi dalam artikel ini menggunakan pendekatan kualitatif-deskriptif yang berusaha untuk mengkaji sumber-sumber literatur dan menguraikan hasil kajiannya secara deskriptif. Utamanya bersumber pada teologi kasih dalam Injil Yohanes. Pendekatan yang digunakan adalah misional hermenutik. Misi Allah adalah inti dari hermenutika yang setia pada Allah. Misi bukan hanya salah satu dari banyak hal yang dibicarakan Alkitab, tetapi mendasari, membentuk, dan menghasilkan teks sehingga membaca Alkitab dengan cara non-misional berarti salah membaca dan salah memahami apa yang Tuhan katakan. ${ }^{5}$ Secara sederhana Misi pertama-tama adalah tentang apa yang Tuhan rindukan kepada seluruh ciptaan-Nya; Misi Allah secara teologis merupakan presaposisi pembicaraan apapun tentang misi umat Tuhan. Tuhan menjalankan tugasnya untuk menebus manusia dengan memilih komunitas untuk bermitra dengan-Nya. Menerima tugas mis Allah membuat misi umat Tuhan harus dipahami dalam kerangka partisipasif, pada panggilan Allah dan perintah, dalam misi Tuhan sendiri ke dunia.

Dalam penelitian ini dipilih ajaran tentang kasih untuk diletakkan di dalam kisah agung Firman Allah, dimana pendekatan ini tetap memperhatikan pendekatan eksegese historis, sastra dan teologis. ${ }^{6}$ Tujuan memahami dengan pendekatan ini supaya 148.

${ }^{3}$ Jan G. van der Watt, "Ethics and Ethos in the Gospel According to John," ZNW 97, no. 3-4 (2006):

${ }^{4}$ D.A. Carson, The Difficult Doctrine of the Love of God (Wheaton, Illinois: Crossway, 2000), 15.

5 Michael W Goheen, “Continuing Steps towards a Missional Hermeneutic," Fideles: A Journal of Redemer Pacific College 3, no. 3 (2008): 50,

http://www.gocn.org/articles/article.cfm?id=24.\%0Ahttps://www.allofliferedeemed.co.uk/Goheen/MW GFideles2008.pdf.

${ }^{6}$ Ailsa Baker, “TEOLOGI, STUDI BIBLIKA, DAN MISI," Indonesian Journal of Theology 2, no. 5 (2017): 103. 
memperlengkapi jemaat sebagai alat misional yang efektif di tengah pemahaman yang luas tentang misi. Maka pertama-tama yang akan dilakukan adalah memberikan uraian singkat tentang Hermenutik Misional dan dilanjutkan dengan menjelaskan konsep kasih dalam Injil Yohanes yang dilihat dari sudut misional dan terakhir memberikan kesimpulan dari hasil penelitian ini.

\section{Hermenutik Misional sebuah Konvergensi}

Salah satu latar belakang yang menstimulasi lahirnya gagasan ini karena perubahan konteks kekristenan di dunia barat dan global. ${ }^{7}$ Barram mengisahkan bahwa selama sekitar satu dekade, para sarjana Alkitab, ahli misi, dan praktisi pelayanan telah berkumpul, setiap tahun, dalam konteks Pertemuan Tahunan paguyuban cendekiawan Sastra Biblika, Annual Meetings of the Society of Biblical Literature, for the Gospel and Our Culture Network (GOCN) tentang Missional Hermeneutics. Tujuan Forum ini untuk mengeksplorasi signifikansi interpretatif dan implikasi dari missio Dei sebagaimana tercermin dalam dan dikomunikasikan oleh keragaman teks dalam kanon Kristen; subbidang baru penafsiran alkitabiah ini telah dikenal sebagai hermenutika misi. ${ }^{8}$ Diduga bahwa pertemuan ini dilatarbelakangi semakin banyak gereja yang membangun atau memaknai konsep misinya berdasarkan pada satu ayat, atau bisa disebut sebagai mencari "dasar alkitabiah untuk misi" namun hal mengalami perubahan menuju kepada menyadari "Dasar misi dari seluruh Alkitab."9 Pendekatan Wright kepada Alkitab ditinjau dari perspektif narasi besar dan membaca keseluruhannya sebagai bagian dari narasi besar Allah yang terungkap dan mendasarkannya dalam teologi biblika. Pendekatan ini menutupi kisah manusia, dimana kisah umat manusia sering kali bertentangan dengan tujuan Tuhan dan berfokus pada pengungkapan narasi besar. Hermenutik misi bukan hanya melihat salah satu dari daftar hal-hal yang kebetulan dibicarakan Alkitab, hanya sedikit lebih mendesak daripada beberapa. Para Misiolog menyatakan bahwa frasa Misi merupakan frasa yang banyak disalahgunakan.

Sebuah pernyataan provokatif muncul dari Goheen yang mengatakan: "if we want to hear what God is saying to his people when we read the Scriptures we must employ a missional hermeneutics." 10 Goheen mau menyakinkan bahwa dengan pendekatan seperti ini akan memberikan cakrawala pengetahuan yang lebih jelas pada saat membaca Alkitab. Dalam hal ini misional hermenutik yang diawali dengan proses exegetical adalah usaha untuk memahami teks dalam misi atau konteks misi dimana implikasi misional teks dikerjakan. Ini juga melibatkan identifikasi niat misionaris penulis suatu bagian atau surat. ${ }^{11}$ Hermenutik merupakan salah satu metode klasik untuk memahami lebih baik bagaimana mendengarkan teks sehingga dapat mendengar dengan benar apa yang Allah katakan kepada umat-Nya dalam Alkitab pada konteks tertentu. Hermenutika mengeksplorasi kondisi dan kriteria yang bekerja untuk mencoba memastikan interpretasi yang bertanggung jawab, valid, bermanfaat atau tepat. ${ }^{12}$ Banyaknya pendekatan yang muncul dan ditawarkan bisa menjadi satu indikator bahwa topik ini

\footnotetext{
${ }^{7}$ Michael W. Goheen, "A History and Introduction to a Missional Reading of the Bible," in Reading the Bible Missionally, ed. Michael W. Goheen (Grand Rapids': Eerdmans, 2016), 6.

${ }^{8}$ Michael Barram, "'Fools for the Sake of Christ': Missional Hermeneutics and Praxis in the Corinthian Correspondence," Missiology: An International Review 43, no. 2 (2015): 196.

${ }^{9}$ Christopher J. H. Wright, The Mission of God: Unlocking the Bible's Grand Narrative (Downers Grove: IVP Academic, 2006), 104.

10 Goheen, "Continuing Steps towards a Missional Hermeneutic," 49.

11 T.M Van Aarde and L. Li-M, "A Fruitful Missional Exegesis for a Missional Hermeneutic and Missiology," In die Skriflig 51, no. 2 (2017): 7.

12 Anthony C. Thiselton, Hermeneutics: An Introduction to Interpretive Theory (Grand Rapids: Eerdmans, 2009), 4.
} 
kompleks dan penting memiliki peran sentral untuk memahami kebenaran. Dalam dunia modern nampak usaha-usaha untuk menawarkan model interpretasi. Di tengah situasi yang menawarkan banyak pandangan hermenutik, seseorang tidak bisa mengabaikan hermenutik.

Hermenutik Misional berkaitan dengan kata Missio Dei yang secara literal dapat diterjemahkan dengan 'Misi Allah', dan hal tersebut sejalan dengan penekanan utama studi ini. Misi lebih tentang Allah dan siapa Dia daripada tentang kita dan natur dari gereja dan semua yang dilakukan. ${ }^{13}$ Misi dalam penelitian ini pertama-tama mengacu pada inisiatif penebusan dan sejarah Allah di dunia ini, terlepas dari tindakan atau tugas atau strategi atau inisiatif yang dilakukan oleh gereja terlebih individu. Berdasar pada gagasan tersebut misi dapat memberikan kerangka kerja baik untuk pendekatan hermeneutis seseorang untuk membaca Alkitab dan untuk mengatur catatan gereja tentang teologi biblika. Tidak dapat disangkali bahwa Alkitab yang pada naturnya sesuatu yang benar-benar 'tentang misi Allah' namun tidak berarti bahwa dalam penelitian seseorang selalu menemukan sesuatu yang relevan dengan penginjilan di setiap ayat Alkitab. Misi terjadi ketika seseorang berpartisipasi dalam missio Dei, melalui pertemuan spontan dan disengaja dengan orang-orang dalam konteks mereka; ini berarti bahwa Injil menemui orang-orang di mana mereka berada. Van Aarde dan Li-M menekankan bahwa hermenutik misional bersifat tekstual dan kontekstual dan bahwa “... itu muncul dari konteks budaya tertentu dan membahas konteks budaya itu melalui penerapan kitab Suci pada konteks budaya atau misi tertentu". Teologi, eklesiologi atau misiologi yang tidak melibatkan konteks tidak memadai dan tidak relevan. ${ }^{14}$ Lebih jelas Bakker menyatakan jika Penafsiran misioner ini tidak memakai metode yang baru atau berbeda. Pertanyaan-pertanyaan historis, kultural, sastra dan eksegese teologis dipertanyakan, tetapi dari perspektif yang berbeda, perspektif misi Allah dalam menebus dan memulihkan dunia yang tercemar oleh dosa. ${ }^{15}$ Dalam pemikiran ini maka kisah misi Allah ke dunia harus menjadi lensa dimana orang percaya memahami isi hati Allah dalam Alkitab. Dengan kata lain hermenutika misional mengingatkan seseorang bahwa kebenaran dalam setiap teks Alkitab berkontribusi untuk membentuk komunitas umat Allah sebagai pelopor bagi kemajuan Injil di setiap konteksnya. Pendekatan kepada pembaca Alkitab yang benar selalu perlu memperhatikan konteks misi komunitas Kristen. ${ }^{16}$

Lebih lanjut, Barram dalam hal ini menegaskan pentingnya konteks di setiap zaman dalam memahami Alkitab secara biblikal, ini sebagai pendekatan terhadap teksteks alkitabiah yang mengutamakan "lokasi" misiologis komunitas Kristen di dunia sebagai kunci hermeneutis. ${ }^{17}$ Barram melihat bahwa ada titik temu yang sangat jelas antara kitab Perjanjian Baru dan bidang misiologi. Itu sebabnya Misional Hermenutik sebagai konvergensi yang tidak terhindarkan. Irisan tersebut menjadi tujuan yang bisa menyadarkan para pembaca Alkitab untuk selalu setia kepada model hermenutik ini. Bisa dikatakan model hermenutik ini merupakan pendalaman dari metode yang sebelumnya ada yaitu 'redemptive-historical analysi. Melaluinya para sarjana perjanjian

13 Timothy C. Tennent, Invitation to World Missions: A Trinitarian Missiology for the Twenty-First Century (Grand Rapids: Kregel, 2010), 55.

14 Aarde and Li-M, "A Fruitful Missional Exegesis for a Missional Hermeneutic and Missiology," 2-5.

15 Baker, "TEOLOGI, STUDI BIBLIKA, DAN MISI," 102.

16 Ibid., 189.

17 Michael Barram, "The Bible, Mission, and Social Location: Toward a Missional Hermeneutic," Interpretation- Journal of Bible and Theology 61, no. 1 (2007): 43. 
baru dan misiolog merumuskan dan mengembangkan natur dari misi Allah sebagai irisan yang penting dalam melihat teks dalam Alkitab.

\section{PEMBAHASAN}

\section{Substansi Kasih dalam Teologi Injil Yohanes}

Konsep kasih pada Injil Yohanes merupakan bangunan teologi sentral yang memainkan peran penting bagi orang Kristen sepanjang sejarah. Sekalipun penting mengulas konsep kasih di dunia pasca-modern merupakan tantangan yang tidak bertepi dan akan memberikan hasil memuaskan. Hal tersebut terjadi karena gelombang budaya yang paling energik, postmodernisme, dengan kuat memperkuat pandangan kasih Tuhan yang paling sentimental, sinkretistik, dan seringkali pluralistik, tanpa basis otoritas lain selain epistemologi postmodern itu sendiri. Tapi itu membuat artikulasi doktrin alkitabiah tentang Tuhan dan kasih Tuhan merupakan tantangan yang luar biasa sulit. ${ }^{18}$ Gambaran yang diamati Carson juga nampak di konteks Indonesia, takkala pemuka-pemuka agama lain nampak lebih menonjolkan ajaran kasih yang banyak dikisahkan dalam Alkitab. Tentu ini menimbulkan pertanyaan kasih seperti apa yang ada pada diri Yesus atau kekristenan yang bisa membedakan dengan yang lain di situasi yang semua hampir sama.

Bisa dikatakan tema kasih terletak di inti Injil Keempat, yang melingkupi setiap aspek Injil ini. Injil Sinoptik juga berfokus pada tema yang sama, akan tetapi dalam Injil Yohanes, Yesus mengarahkan murid-muridnya untuk mengasihi Allah dan sesama mereka (13:34;15:12), berdasarkan Ulangan 6:4-5 dan Imamat 19:18. Injil Yohanes, satu-satunya Injil yang membingkai perintah Yesus bagi murid-muridnya adalah untuk saling mengasihi (15:12). Dalam hal ini, dia menyatakan keyakinan bagi pembacanya bahwa Allah dalam Kristus mengasihi mereka yang menaati perintah-perintah-Nya $(14: 21,23)$. Alih-alih sekadar menjelaskan kasih dalam kehidupan Yesus, Yohanes menunjuk bahwa pada kematian Yesus merupakan sebuah contoh dari tipe kasih yang Yesus harapkan untuk dimiliki oleh murid-muridnya (lih. 3:16; 15:13). Di samping itu, korpus Yohanes yang hanya seperlima dari volume Perjanjian Baru (19\%), itu menyajikan hampir setengah dari kejadian "percaya" (107 dari $228=47 \%$ ), lebih dari sepertiga dari "tahu" (190 dari $508=37 \%$ ) dan lebih dari setengah dari kata kerja "kasih" (85 dari $154=55 \%$ ). Membandingkan Injil Yohanes saja dengan Injil Sinoptik sebagai sebuah kelompok, di situ ditemukan hampir tiga kali lipat jumlah kemunculan "percaya" (98 dalam Yohanes, 35 dalam Sinoptik), yang keempat lebih banyak dari yang "tahu" (133 dalam Yohanes, 106 dalam Sinoptik), dan tidak jauh dari dua kali lebih banyak dari "kasih" (50 dalam Yohanes, 30 dalam Sinoptik). ${ }^{19}$ Jumlah ini bisa menjadi satu indikator yang kuat bahwa ada suatu kelebihan yang dicatat Yohanes bagi orang percaya tentang arti kasih. ${ }^{20}$

Secara umum Injil Yohanes bisa diamati dari lensa misional dalam 2 bagian besar, pasal 1-12 dan Pasal 13-21. Dalam pasal 1-12 berfokus pada Yesus sang Mesias sebagai Anak yang diutus oleh Bapa, dengan penekanan pada dimensi "horizontal" dari misi Yesus, sedangkan pasal 13-21 memandang Yesus terutama sebagai Dia yang datang ke dunia dan kembali kepada Bapa, dengan penekanan pada dimensi "vertikal" dari misi Yesus. Bagaimanapun, 20: 30-31 memasukkan 1-12 dan 13-20 di bawah tujuan penulisan Injil keempat, supaya dunia mengenal siapa Allah yang telah mengutus Kristus. Pengambaran Yesus sebagai guru-gembala eskatologis mencakup pasal 1-21

\footnotetext{
${ }^{18}$ Carson, The Difficult Doctrine of the Love of God, 14.

19 Paul A. Rainbow, Johannine Theology: The Gospel, the Epistles and the Apocalypse (Downers Grove: InterVarsity, 2014), 289-90.

${ }^{20}$ Carson, The Difficult Doctrine of the Love of God, 160.
} 
dan dengan demikian memberikan elemen pemersatu dalam kerangka narasi Injil, yang mencakup pengumpulan murid-murid Yesus serta pengumpulan buah sebagai hasil bagi Yesus. ${ }^{21}$ Dalam bingkai misi ada berbagai tema utama lain yang memainkan peran dalam Injil Yohanes yang tidak bisa diabaikan seperti misalnya kata percaya (pisteuo) yang disebutkan lebih dari 90 kali.

Pengertian kasih dalam Injil keempat menunjukkan bahwa membutuhkan pemahaman lebih dari apa yang Yesus ajarkan dalam Injil. Ini membutuhkan pemahaman atas tindakan dan implikasinya, bahkan dalam pasal yang tidak menggunakan terminologi untuk kasih. Jeanrond mengatakan, "Thus it concerns a broad network of interdependent relationships: between God and God's creation; God and human beings; God and the Church; between human beings and God; between one human being and another; between human beings and the universe, between human beings and their diverse cultural and religious traditions and expectations; and between every human being and her or his own emerging self." 22 Hal ini jelas menunjukkan bagaimana kasih merupakan topik yang memiliki peranan besar bagi manusia secara spiritualitas dan kompleks untuk dipelajari. Di saat yang bersamaan menjadi sesuatu yang dibutuhkan manusia di tengah dunia. Terlebih pada konteks Yohanes dan gereja mula-mula. Ajaran fundamental yang menjadi hal utama tentang kasih utamanya terkait setiap orang percaya dalam mengasihi Allah dan sesama. Sekalipun dalam teologi Yohanes terjadi pergeseran paradigma tentang kasih yang sebelumnya luas menjadi khusus di tengahtengah orang percaya. ${ }^{23}$ Kasih yang berkorban, kasih yang tidak egois, kasih yang memulihkan menjadi gambaran tentang implikasi bagi orang percaya sampai sekarang. Tetapi pergeseran ini tentu terlihat dari setiap peristiwa yang ada saat ini.

Akan tetapi, jika seseorang memperhatikan pusat teologi Yohanes, maka dengan sadar akan melihat bahwa gagasan kasih dan kehidupan menjadi pusat dan pesan utama Yohanes. Dogmatiknya diringkas dalam kata bahwa Allah lebih dulu mengasihi kita. Dilanjutkan kepada dasar etika-Nya dalam nasihat: Oleh karena itu marilah kita mengasihi Dia dan saudara-saudara. Nasihat tersebut menjadi konsep gagasan yang berbeda pada zaman itu. Hanya, seseorang tidak boleh memahami kata ini secara sentimental atau perasaan subjektif belaka, tetapi dalam arti esensial yang terdalam dan paling murni. Kasih Tuhan adalah komunikasi diri-Nya dengan manusia; dalam arti lain kasih manusia juga harus diwujudkan dalam pengudusan diri yang suci dari Allah.

Lebih daripada itu, kasih dalam Injil Yohanes membawa pembaca ke dalam dunia sastra dan teologis Injil untuk menunjukkan bagaimana berbagai tema Yohanes mencapai puncaknya dalam kematian Yesus. ${ }^{24}$ Sekalipun ini juga ada di kitab Injil lainnya. Yohanes menggambarkan karya Kristus di atas salib sebagai subtitusi dan pengorbanan diri. Tidak ada kualitas lain dari karakter ilahi, yang nyata atau tersembunyi, dapat tidak selaras dengan peristiwa salib tersebut. Tuhan mengundang manusia untuk masuk ke dalam Dia dengan keyakinan bahwa setiap pemandangan baru yang Dia buka untuk gerejanya akan sejalan dengan kasih yang telah Ia hidupi selama berada sepanjang sejarah. ${ }^{25}$

${ }^{21}$ Andreas J. Köstenberger, The Missions of Jesus and the Disciples According to the Fourth Gospel: With Implications for the Fourth Gospel's Purposes and the Missions of The (Grand Rapids: Eerdmans, 1998), 140.

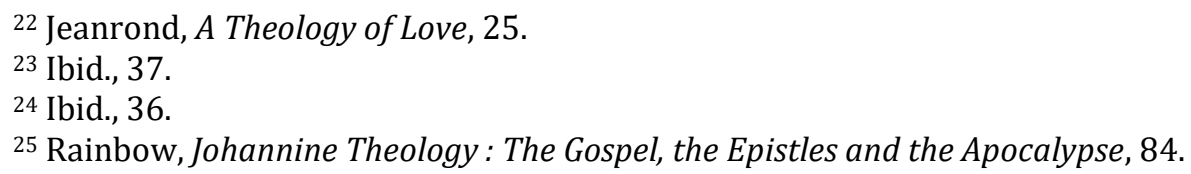


Mengenal Tuhan begitu terikat dengan berpegang pada kebenaran, melakukan kehendak-Nya dan menunjukkan kasih, itulah kriteria yang digunakan untuk menentukan apakah pengetahuan yang diakui tentang Tuhan sejati dan esensial. ${ }^{26}$ Ini satu perbedaan yang bisa menjawab pertanyaan utama. Kasih sejati dalam kekristenan merupakan perwujudan iman seseorang kepada sumber kasih sejati yang digerakkan oleh Roh Kudus. Sehingga siapapun yang memiliki kasih dari Allah ia tidak akan binasa karena dosanya. Itu sebabnya, kasih tidak memiliki makna jika tidak diungkapkan dalam bentuk dan sikap yang nyata. Dalam teologi Yohanes, kasih adalah ketaatan. Yesus berkata "jika kita mengasihi-Nya, kita akan menuruti perintah-Nya" (Yoh. 14:15; 14: 2124). Bahkan, perintah-Nya menjadi kesempatan untuk menunjukkan kasih (15:17). Jadi, dalam percakapan Yesus dengan Petrus (21: 15-19) pertanyaan tentang kasih Petrus diuji terhadap panggilan untuk memelihara dan mengasihi pengikut Kristus. Ketaatan seperti itu menjadi bukti pemuridan: "Kami tahu bahwa kami telah mengenal dia jika kami menuruti perintah-perintahnya" (1Yoh. 2:3). Dari sudut pandang yang lain takkala Yesus mengacu pada kesejahteraan (weel-being) nampak ketika Ia memanggil agar setiap manusia dapat memiliki "hidup, dan memilikinya secara berlimpah" (Yoh. 10:10) Yesus juga mengungkapkan kasih. Dengan demikian, meningkatkan kesejahteraan ketika Dia menyembuhkan orang sakit dan mengusir setan. Frasa "kesejahteraan" telah disamakan dalam literatur lain dan dalam Alkitab dengan kesehatan, penyembuhan, kebahagiaan, keutuhan, pengobatan dan berkembang. ${ }^{27}$

Kasih dalam kekristenan bukan suatu konsep dangkal dan singkat sebagaimana yang dunia tawarkan dan pertunjukkan. Dalam hal ini menyatakan berdasar dari apa yang telah Ia lakukan dan perlukan dilakukan bagi orang percaya sebagai pengikutNya. ${ }^{28}$ Pelayanan publik yang dilakukan Yesus dijadikan contoh dalam ajaran Yesus tentang hubungannya dengan Bapa bahkan ketika Yesus melakukan tindakan kasih yang terakhir melalui pengorbanan diri-Nya. Kematian-Nya menjadi pembaruan yang mendorong orang-orang percaya untuk mengasihi yang diungkapkan Yesus. Milne menyebutnya sebagai sebuah evangelistic power of love, sesuatu masyarakat yang mengasihi, kata Yesus merupakan pembuktian Injil secara nyata, di sini kasih menjadi sebuah apologetik terakhir. ${ }^{29}$ Seorang Misionaris abad pertengahan Fransiskus Asisi pernah berkata, Preach the Gospel at all time and if necessary use words. Maknanya Injil harus dihidupi dalam kehidupan, jika dibutuhkan gunakanlah kata-kata. Di sini menghidupi Firman jauh lebih penting dibanding dengan perkataan-perkataan. Dengan kata lain kasih dalam teologi Yohanes menuntut sebuah sikap nyata juga yang membentuk setiap aspek hidup manusia yang mampu mempengaruhi lingkungan sekitarnya.

\section{Perspektif Misional dalam Injil Yohanes melalui Kasih}

Kata agape dalam Injil Yohanes akan menjadi pusat perhatian dalam bagian ini. Sekalipun dalam bagian ini tidak dapat mengurai seluruh makna misional yang terkandung. Sebagaimana telah dijelaskan pada bagian sebelumnya. Sekalipun pada bagian tertentu tidak tersurat kata agape di dalamnya banyak narasi dalam Injil Yohanes yang menyiratkan makna kasih (agape) yang mendalam. Sebagai contoh bahwa perlu diperhatikan kasih dalam narasi yang Yohanes bangun dari awal adalah pengajaran yang tidak peduli dengan pengertian kasih sebagai seperti itu, tetapi dengan karya kasih

26 Ibid., 307.

27 Thomas Jay Oord, “The Nature of Love: A Theology” (Louis Missouri: Chalice Press, 2010), 18-19, http://www.amazon.com/dp/0827208286.

28 Bruce Milne, Yohanes; Lihatlah Rajamu (Jakarta: YKBK, 2010), 303.

${ }^{29}$ Ibid., 304. 
itu sendiri. Narasi tentang firman datang di tengah dunia (Yoh. 1:1-18) menunjukkan kasih Allah terbesar supaya dunia mengenal Allah dan Ia yang akan menyelamatkan miliknya sendiri. Soren Kierkegaard mengatakan, kasih yang Allah tunjukkan melalui Yesus Kristus adalah kasih yang misterius yang tidak bisa terselami sepenuhnya oleh manusia biasa, Karena membutuhkan Allah sendiri yang menyatakannya kepada manusia (Yoh. 1:18).

Kata "dunia" dalam Injil Yohanes biasanya tidak mengacu pada tempat yang besar dengan banyak orang di dalamnya, tetapi ke bisa juga situasi yang buruk dengan banyak orang jahat di dalamnya. Kata "dunia" dalam Injil Yohanes adalah tatanan ciptaan yang berpusat pada manusia, yang telah Allah buat dan yang memberontak melawan dalam kebencian dan penyembahan berhala, yang mengakibatkan hubungan yang rusak, perselingkuhan, dan kejahatan. ${ }^{30}$ Itulah sebabnya di ayat-ayat pertama Injil ini, dalam satu bagian Yohanes menyajikan dua pasal sebelumnya, yang disebut pengantar Injil Yohanes (Yoh. 1:1-18). Artinya, dengan kedatangan Yesus datanglah pengungkapan diri Allah yang murah hati, wahyu-Nya, terang yang baik dan bersih dan murni - tetapi manusia cinta kegelapan, bukan terang. Orang tidak ingin terkena cahaya seperti itu. Maka apa yang dilakukannya hanyalah menunjukkan kerusakan yang dibungkus dengan berbagai moralitas duniawi yang sia-sia. Ke situlah Allah memberikan tugas kepada setiap orang percaya untuk menyinari dan menyatakan kebenaran-Nya.

Kasih agape adalah kasih yang berorientasi membawa kebenaran kepada kekekalan. Bersumber dari Allah karena Allah adalah kasih itu sendiri. Sebagaimana Rainbow mengatakan lebih lanjut, "kasih yang berasal dari Allah dan direspons oleh makhluk menjembatani jurang ontologis dan logis antara yang tak terbatas dan yang terbatas. Metode apofatik dalam teologi menekankan jurang, menunjukkan bagaimana semua metafora akhirnya gagal, dan cenderung agnostisisme mistik. Tepat meskipun keengganannya, pendekatan ini bukanlah kata terakhir karena Allah telah menyatakan diri-Nya sebagai kasih dengan mengirimkan Anak-Nya menjadi pendamaian dosa (1Yoh. 4:9-10)." 31 Ini adalah kasih sekaligus merupakan misi Allah dalam menyelamatkan manusia yang telah jatuh dalam dosa. Selanjutnya pada ayat 3:16 (agapao) menjadi bagian pertama yang menjelaskan makna kasih agape. Dalam narasi ini terlihat bahwa Kristus mengklaim wahyu khusus: Dia dapat berbicara secara otoritatif tentang kebutuhan manusia akan keselamatan melalui kelahiran baru. Ini sebuah misi untuk mendamaikan manusia dengan Allah dan mengarahkan kembali rancangan kehidupan manusia sesuai dengan penciptanya. ${ }^{32}$ Baik Rainbow maupun Carson melihat kasih sebagai sesuatu yang esensi dalam inkarnasi dan juga otoritas-Nya untuk menyelamatkan manusia.

Agape dan eros banyak dikontraskan dalam kitab Injil demikian juga dalam Injil Yohanes. Keduanya dikontraskan sebagai motif utama agama Kristen dan non-Kristen. Konsep Perjanjian Baru berbeda dengan agama Yahudi yang sudah ada pada saat itu. Terlepas dari banyaknya kedekatan dan hubungan antara Yudaisme dan Kristen, ajaran Kristus adalah hal yang secara fundamental berbeda dari Yudaisme. Sementara hukum dalam Yudaisme merupakan ikatan antar manusia, itu adalah persekutuan yang baru dilembagakan dengan Tuhan dalam agama Kristen yang memberi gagasan tentang makna Agape maknanya. Kekeliruan dalam cara membaca pasal 3:16 nampak kadangkadang dalam sejarah gereja, orang Kristen lebih menekankan pada murka Tuhan atau

30 D.A. Carson, The Gospel According to John (Grand Rapids: Eerdmans, 1991), 161.

${ }^{31}$ Rainbow, Johannine Theology: The Gospel, the Epistles and the Apocalypse, 138.

32 Carson, The Difficult Doctrine of the Love of God, 139. 
kedaulatan-Nya atau kekudusan-Nya, semua tema yang alkitabiah dalam beberapa derajat atau lainnya. ${ }^{33}$ Kasih Tuhan tidak menerima sebanyak perhatian itu. Namun, akhir-akhir ini jika orang percaya pada Tuhan, pada umumnya mereka merasa mudah untuk percaya pada kasih Tuhan.

Yesus mengembangkan perintah untuk mengasihi Allah dari Perjanjian Lama, mengisinya dengan nilai-nilai baru dengan mengaturnya dalam kaitannya dengan persekutuan baru dengan Tuhan yang telah Dia hadirkan di tengah dunia. ${ }^{34}$ Secara khusus dapat dikatakan bahwa universalitas Kasih dalam kekristenan melampaui batasbatas kebenaran hukum Yahudi dalam Perjanjian lama. Hal tersebut dapat dilihat dalam dua cara: mencakup semua manusia dan bahkan termasuk orang berdosa. Inilah kasih dalam kristen yang merupakan sesuatu selain dari kasih manusia biasa yang berasal dari bukan Allah. Itulah yang ditegur Yesus dengan berkata: "Tetapi tentang kamu, memang Aku tahu bahwa di dalam hatimu kamu tidak mempunyai kasih akan Allah" (5:42).

Pada pasal 3:35 Yohanes mencatat bahwa Allah Bapa mengasihi Allah Anak melaluinya Allah Bapak telah menyerahkan segala sesuatu ke dalam tangan-Nya dan telah menetapkan bahwa semua harus menghormati Anak sama seperti mereka. menghormati Bapa. Jadi, secara eksplisit, Alkitab menyatakan bahwa Bapa mengasihi Putra. Itu juga memberitahu kita, sama eksplisitnya, bahwa Anak mengasihi Bapa dan selalu melakukan apapun yang menyenangkan Dia (lih. 14:31). Pertama-tama, mengapa Yesus disalibkan karena dia mengasihi Bapa-Nya dan melakukan kehendak Bapa-Nya. Kasih berada di dalam Ketuhanan ini (yang disebut orang sebagai kasih intratrinitas Allah -Allah Tritunggal, maka yang perlu dipikirkan bahwa kasih yang mengalir di antara Allah Tritunggal) adalah kasih yang sempurna. Dalam konteks manusia sebagai umat Allah maka tindakan misional Allah Tritunggal nyata dalam setiap umatnya terlebih pada Kristus sejak Dia berada di bumi sampai ketika Ia mengutus Allah Roh Kudus (8:42).

Dalam teologi Injil dan utamanya Yohanes telah menunjukkan bahwa sikap ketaatan-Nya dalam menjalankan tugas yang diberikan Allah Bapa menuntun pada kematian-Nya. Ini menunjukkan kasih yang bebas dan sukarela bagi Bapa-Nya. Hanya sekali dalam literatur Yohanes Yesus dikatakan mengasihi Bapa, dan itu tepat sebelum kematian-Nya: "Aku melakukan seperti yang diperintahkan Bapa kepada-Ku, supaya dunia tahu, bahwa Aku mengasihi Bapa" (Yoh. 14:31). Karena alasan ini, Bapa mengasihi Dia (Yoh 10:17). Dengan demikian kasih abadi Bapa kepada Putra diteguhkan (Yoh 3:35; 5:20; 15:9-10; 17:23-24, 26), dan dibalas oleh Putra, di atas kayu salib.

Bagian kedua mulai pasal 13-21, Yohanes melukiskan bagaimana kasih Yesus kepada murid-murid-Nya (lih. 13:1). ${ }^{35}$ Menarik apa yang dilakukan Yohanes bagaimana mendemonstrasikan dalam jumlah kemunculan kata untuk "kasih" mendahului kalimat ini; empat puluh lima mengikuti. Murid yang dikasihi Yesus muncul dalam cerita (Yoh. $13: 23 ; 19: 26 ; 20: 2 ; 21: 7,20)$. Kasih Yesus kepada murid-murid-Nya menjadi dasar perintah baru bagi komunitas orang percaya dan menjadi teladan bagi mereka untuk saling mengasihi (Yoh. 13:34-35; 15:12-13, 17). Yesus meyakinkan kasih-Nya kepada mereka (Yoh. 15:9-10) dan menyiratkan bahwa Dia akan mengungkapkannya secara konkret di atas segalanya dengan mati bagi mereka (Yoh. 15:13).

Pasal 13-17 menjadi satu kesatuan terdekat yang perlu dipahami sebagai konteks yang saling terkait dengan pasal sebelum dan sesudahnya dalam pasal 15:9-17. Secara khusus yang menjadi bagian fokus kita adalah ayat 15:16 "dan Aku telah menetapkan

\footnotetext{
33 Ibid., 136.

34 Jeanrond, A Theology of Love, 116.

35 Rainbow, Johannine Theology: The Gospel, the Epistles and the Apocalypse, 205.
} 
kamu, supaya kamu pergi dan menghasilkan buah dan buahmu itu tetap." Ayat ini merupakan menjadi pusat dari pasal perpisahan Yesus dalam Injil Yohanes. ${ }^{36}$ Dimana ajaran kasih yang telah disampaikan harus dilakukan segera sambil menunggu Roh Kudus yang dijanjikan. Bagian dari ayat ini penting dalam memberikan kontribusi bagi pemahaman tentang perintah kasih Yesus di Injil Yohanes. Tidak ada sedikit perdebatan tentang sejauh mana wacana perpisahan, meskipun secara luas diakui bahwa beberapa atau seluruh Yohanes 13-17 merupakan narasi perpisahan yang koheren dimaksudkan untuk mempersiapkan para murid untuk kepergian Yesus. ${ }^{37}$

Dalam pasal 15 terlihat pergeseran sifat indikasi di ayat 1-3 ke imperatif di ayat 417. Implikasi yang jelas mengalir dari hubungan posisi yang dimiliki para murid dengan Yesus. Ini bukanlah hubungan hak istimewa belaka; ada tanggung jawab yang terlibat. Ayat 4-8 secara eksplisit berfokus pada menghasilkan buah. Kita melihat referensi lain kepada manusia di mana Yesus telah mengasihi murid-muridnya di ayat 9: "seperti Bapa telah mengasihi aku, demikian juga aku mengasihi kamu." Kesatuan yang dimiliki oleh Bapa dan Anak ditawarkan kepada para murid jika mereka tetap dalam kasih-Nya. "Menghasilkan buah" dalam konteks ini pada akhirnya adalah tentang ekspresi kasih menjadi lebih jelas dalam ayat 12-17. Di mana kasih menjadi penekanan utama, dan pengorbanan diri menjadi ekspresinya. Tampak jelas bahwa ayat 12-17 membentuk sub-unit yang koheren karena dua ayat yang membingkai membentuk inklusio dengan pernyataan eksplisit "saling mengasihi".

Dalam konteks seperti itu Yesus kembali memerintahkan murid-murid-Nya untuk "saling mengasihi seperti Aku telah mengasihimu" (ayat 12). Ini segera mengingat katakata dari 13: 1, 34-35. Bagaimana Yesus menunjukkan kasih kepada mereka? Dia telah mencintai mereka, eis telos - sepenuhnya dan seutuhnya. Di atas, saya berpendapat bahwa dalam pencucian kaki seseorang dapat melihat tindakan simbolis dan profetik yang mengantisipasi penyaliban. Yesus membuat ajaran itu menjadi eksplisit: "Tidak ada kasih yang lebih besar dari pada kasih ini, bahwa Ia telah menyerahkan nyawa-Nya untuk teman-temannya." Konteks "saling mengasihi" selain mengandung perintah imperatif juga berisi bermuatan misional. Wacana Perpisahan terdiri dari sekelompok tema yang saling terkait, tetapi semuanya terhubung dengan tema misi yang menyeluruh dalam Injil Yohanes, yang berpuncak pada doa misi yang panjang dan pengutusan di pasal 17. Seruan untuk "saling mengasihi," dan untuk kesatuan yang dihasilkan oleh kata semacam itu, tidak pernah jauh dari kata-kata tentang pengutusan dan kesaksian para murid. Konteks Misional dalam pasal 15 adalah pergi dan menghasilkan buah. Mengasihi satu sama lain tidak membutuhkan murid untuk pergi ke mana pun, tetapi mengasihi dunia yang tidak bersahabat pasti melakukannya (15:16, "pergi").

Perintah dan teladan kasih Yesus tidak berakhir dengan kasih di antara para murid, juga tidak memiliki kesatuan internal sebagai tujuan akhir mereka. Kasih dan persatuan seperti itu dimaksudkan untuk membawa orang lain ke dalam kasih dan kehidupan ilahi. "Sebagaimana kamu telah mengutus aku ke dunia, demikian pula Aku telah mengutus mereka [murid-muridnya] ke dunia," doa Yesus (17:18). Artinya, para murid diutus karena kasih ilahi, dibagikan di antara mereka sendiri, untuk membawa orang lain, bahkan para pembenci dan penganiaya, ke dalam kasih Bapa, Putra, dan

${ }^{36}$ Frances Taylor Gench, “John 15:12-17," Interpretation 58, no. 2 (2004): 181.

37 "Pembaca Yohanes 13-17 dengan cepat mengetahui bahwa kumpulan materi yang tampaknya tidak teratur ini sangat masuk akal jika dipandang sebagai pidato perpisahan" (Neyrey, Gospel of John, 238). 
komunitas. Sebuah himne Brian A. Wren meringkas sentimen Yohanes: "Kita akan pergi dengan sukacita, untuk memberi dunia, kasih yang menjadikan kita satu." Ini memberikan kerangka bagi misi Kristen sebagai pewartaan Kerajaan Allah, untuk membagikan kasih Yesus Kristus kepada semua orang dan menjadi saksi karya Roh yang penuh kuasa.

Jadi, dalam konteksnya, "saling mengasihi" mencakup kasih untuk dunia dan musuh. Dalam hal seperti inilah hermenutik misional diterjemahkan dalam berbagai bentuk-bentuk konret yang kontekstual. Pada akhirnya karena "Tuhan begitu mengasihi dunia," dan karena Yesus menunjukkan kepada manusia seperti apa kasih ilahi itu, sehingga orang percaya dapat meniru Dia dan berpartisipasi dalam kehidupan ilahi. Ini merupakan spiritualitas partisipasi, bahkan teosis, yang secara inheren bersifat misional yang merupakan sepantasnya ada di semua gereja sebagai naturnya. Hermenutik misional sebagai cara membaca Alkitab dengan misi sebagai kepentingan dan tujuan utamanya. Maka menunjukkan dengan jelas bahwa kasih dalam Injil Yohanes bersifat universal sekaligus pratikular. Keduanya hidup dan berpartisipasi dalam kehidupan Tuhan, menurut Yohanes, adalah mampu mengasihi orang lain, termasuk musuh. Gereja terlibat dalam setiap aspek kehidupan manusia untuk hadir menyatakan kasih yang dapat mengubah lingkungannya.

\section{KESIMPULAN}

Studi ini menunjukkan bahwa kasih dalam Injil Yohanes merupakan hal esensial yang berorientasi membawa kepada kekekalan dan memainkan peran sentral dalam misi Allah. Dimana kasih akan disempurnakan pada masa yang akan datang. Namun pada zaman sekarang Gereja memiliki kasih tersebut karena Allah yang memberikan. Gereja adalah kasih sebagaimana Allah itu kasih, sehingga natur gereja yang sejati senantiasa menyatakan kasih yang menyelamatkan. Menyatakan dan memberi kasih merupakan natur alami gereja maupun orang percaya yang merupakan hal esensial dimana misi Allah itu berada. Namun tidak semua orang percaya memiliki kemampuan untuk mengkomunikasikan dan menjelaskan atribut atau kualitas Allah yang belum pernah dilihat siapa pun (Yoh. 1:18; 1Yoh. 4:12, lih. 4:20). Itu sebabnya berbicara tentang kasih adalah sebuah topik tanpa batasan. Orang Kristen percaya pada kasih, pengampunan dan kasih karunia Tuhan, tetapi tidak akan pernah memahaminya sepenuhnya; meskipun, seseorang masih perlu terus menyelidikinya.

\section{Referensi}

Aarde, T.M Van, and L. Li-M. "A Fruitful Missional Exegesis for a Missional Hermeneutic and Missiology." In die Skriflig 51, no. 2 (2017): 1-0.

Baker, Ailsa. "TEOLOGI, STUDI BIBLIKA, DAN MISI." Indonesian Journal of Theology 2, no. 5 (2017): 147-177.

Barram, Michael. "'Fools for the Sake of Christ': Missional Hermeneutics and Praxis in the Corinthian Correspondence." Missiology: An International Review 43, no. 2 (2015): 195-207.

_—_. "The Bible, Mission, and Social Location: Toward a Missional Hermeneutic." Interpretation-Journal of Bible and Theology 61, no. 1 (2007): 42-58.

Bevans, Stephen B., Darrell L. Guder, Ruth P. DeBorst, Edward Rommen, and Ed Stetzer. The Mission of the Church. Edited by Craig Ott. Grand Rapids: Baker Academic, 2016. Carson, D.A. The Difficult Doctrine of the Love of God. Wheaton, Illinois: Crossway, 2000. 
Gench, Frances Taylor. “John 15:12-17.” Interpretation 58, no. 2 (2004): 181.

Goheen, Michael W. "A History and Introduction to a Missional Reading of the Bible." In Reading the Bible Missionally, edited by Michael W. Goheen, 3-27. Grand Rapids': Eerdmans, 2016.

Goheen, Michael W. "Continuing Steps towards a Missional Hermeneutic." Fideles: A Journal of Redemer Pacific College 3, no. 3 (2008): 49-99. http://www.gocn.org/articles/article.cfm?id=24.\%0Ahttps://www.allofliferedeem ed.co.uk/Goheen/MWGFideles2008.pdf.

Jeanrond, Werner G. A Theology of Love. New York: T\&T Clark International, 2010.

Köstenberger, Andreas J. The Missions of Jesus and the Disciples According to the Fourth Gospel: With Implications for the Fourth Gospel's Purposes and the Missions of The. Grand Rapids: Eerdmans, 1998.

Labuschagne, Pieter HJ. "A Missional Hermeneutic for the Transformation of Theological Education in Africa." HTS Teologiese Studies / Theological Studies 75, no. 4 (2019): 212-227.

Milne, Bruce. Yohanes; Lihatlah Rajamu. Jakarta: YKBK, 2010.

Oord, Thomas Jay. "The Nature of Love: A Theology." Louis Missouri: Chalice Press, 2010. http://www.amazon.com/dp/0827208286.

Rainbow, Paul A. Johannine Theology: The Gospel, the Epistles and the Apocalypse. Downers Grove: InterVarsity, 2014.

Tennent, Timothy C. Invitation to World Missions: A Trinitarian Missiology for the TwentyFirst Century. Grand Rapids: Kregel, 2010.

Thiselton, Anthony C. Hermeneutics: An Introduction to Interpretive Theory. Grand Rapids: Eerdmans, 2009.

Watt, Jan G. van der. "Ethics and Ethos in the Gospel According to John." ZNW 97, no. 3-4 (2006): 147-75.

Wright, Christopher J. H. "Mission as a Matrix for Hermeneutics and Biblical Theology." In Out of Egypt: Biblical Theology and Biblical Interpretation, edited by Craig Bartholomew, Mary Healy, Karl Möller, and Robin Parry. Grand Rapids: Zondervan, 2004.

- - - The Mission of God: Unlocking the Bible's Grand Narrative. Downers Grove: IVP Academic, 2006. 